\section{Seed quality analysis of Senna siamea Lam. using image analysis techniques}

\author{
Jackson Araújo da Silva ${ }^{1}$, André Dantas de Medeiros ${ }^{2 *}$ (iD), Márcio Dias \\ Pereira ${ }^{1}$ (D) Amanda Karoliny Fernandes $\operatorname{Ramos}^{1}$ (D) , Laércio Junio da Silva²
}

ABSTRACT: The inclusion of image analysis techniques for the accurate and rapid assessment of the quality of forest seeds is highly desirable. The use of digital radiographic images of seeds and the analysis of seedling images, still little used in determining the quality of forest seeds, are among the available imaging techniques. This study aimed to assess the feasibility of using the analysis of images of seeds and seedlings in the assessment of the physical and physiological quality of Senna siamea seeds. Radiographic images of seeds were obtained from five seed lots, allowing generating morphological and tissue integrity descriptors. These seeds were then subjected to germination and seedling growth tests, which allowed obtaining variables related to physiological quality. The generated seedlings were scanned and analyzed using the software ImageJ. The data were analyzed using analysis of variance, correlation, and principal component analysis. The results showed differences between seed lots in terms of physiological quality and physical integrity of internal tissues. Significant correlations were observed between the variables obtained with the radiographic analysis and seed physiological characterization tests. The use of techniques to analyze seed radiographs and seedling images allows access to information on the physical and physiological integrity of $S$. siamea seeds.

Index terms: multivariate analysis, forest seed, seed radiography.

\section{Análise da qualidade de sementes de Senna siamea Lam. por meio de técnicas de análise de imagens}

RESUMO: A inclusão de técnicas de análise de imagens para a avaliação precisa e rápida da qualidade de sementes florestais é altamente desejável. Entre as técnicas de imagem disponíveis, destacam-se o uso de imagens radiográficas digitais de sementes e a análise de imagens de plântulas, ainda pouco utilizadas na determinação da qualidade de sementes florestais. Objetivou-se com este trabalho, avaliar a viabilidade do uso da análise de imagens de sementes e plântulas na avaliação da qualidade física e fisiológica de sementes de Senna siamea. Imagens radiográficas de sementes de cinco lotes foram obtidas e, a partir delas, foram gerados descritores morfológicos e de integridade tecidual. Após a obtenção das imagens das sementes, estas foram submetidas ao teste de germinação e crescimento de plântulas, dos quais se extraíram variáveis relacionadas à qualidade fisiológica. As plântulas geradas foram escaneadas e analisadas por meio do software ImageJ. Os dados foram analisados por meio da análise de variância, correlação e análise de componentes principais. Os resultados mostraram diferenças entre os lotes de sementes quanto a sua qualidade fisiológica e integridade física de tecidos internos. Foram observadas correlações significativas entre as variáveis obtidas com a análise radiográfica e pelos testes de caracterização fisiológica das sementes. $O$ uso das técnicas de análise de radiografias de sementes e de imagens de plântulas permitem acessar informações de integridade física e fisiológica de sementes de $S$. siamea.

Termos para indexação: análise multivariada, semente florestal, radiografia de sementes.
Journal of Seed Science, v.42, e202042042, 2020

http://dx.doi.org/10.1590/ 2317-1545v42241633
E-mail: medeiros.seeds@gmail.com

Received: 7/30/2020.

Accepted: $11 / 9 / 2020$

\footnotetext{
${ }^{1}$ Unidade Acadêmica Especializada em Ciências Agrárias, Universidade Federal do Rio Grande do Norte, 59280-000 - Macaíba, RN, Brasil.

${ }^{2}$ Departamento de Agronomia, Universidade Federal de Viçosa, 36570-900 - Viçosa, MG, Brasil.
} 


\section{INTRODUCTION}

Senna siamea Lam. is a tree of Asian origin adapted to regions with a semi-arid climate and used for medicinal and food purposes (Hassan et al., 2015), to obtain cellulosic ethanol (Mund et al., 2016), and in reforestation and forest restocking programs (Parveen et al., 2010). However, the production of healthy tree seedlings with potential for establishment in the field depends initially on seed quality.

Seed quality of forest species can be compromised by several factors, such as the occurrence of insect attack, the formation of empty seeds or malformed embryos (Gomes et al., 2014), and the deterioration resulting from delays in harvesting (Silva et al., 2018) or after harvest during storage. Thus, quality analysis is essential to guarantee the successful use of these seeds, especially their physiological potential. The characterization of the physiological potential of seeds is obtained using the germination test and vigor analysis. Germination is the official procedure for determining the capacity of seeds to produce normal seedlings under laboratory conditions (Brasil, 2013). New analyses have been proposed to complement the information provided by the germination test and other attributes that comprise seed quality, many of them seeking faster, more accurate, non-destructive, and less subjective procedures (EIMasry et al., 2020; Medeiros et al., 2020; Pinheiro et al., 2020; Xia et al., 2019).

Image analysis technologies have shown great potential to be used associated with traditional tests to assess seed quality, guiding human observation from the perception and precision of machines. This type of approach can provide significant advances not only in the standardization of methodologies but also in obtaining results with a high level of reliability and reproducibility (Toda et al., 2020). X-ray and image analysis of seedlings have gained prominence for the assessment of physical and physiological attributes in seeds.

$\mathrm{X}$-ray analysis is a fast and non-destructive procedure to access information on the internal morphology of seeds (Gomes-Junior and Cicero, 2012). The analysis allows the visualization of the occurrence of malformed, empty, mechanically damaged, and insect-damaged seeds, which have the potential to negatively influence the germination capacity. Digital images of seedlings allow for fast and accurate differentiation of lots with different vigor levels (Castan et al., 2018; Pereira et al., 2020). The processes that involve the analysis of seedlings are based on image acquisition using a scanning device, followed by post-evaluation by software (Trujillo et al., 2020). Seedling length data can be used to generate seedling performance indices involving variables of uniformity and vigor. Software, such as SVIS (Sako et al., 2001), Vigor-S (Castan et al., 2018), SAPL (Pereira et al., 2020), and Groundeye (Lima et al., 2018), have been used for digital analysis of seedling length. Also, the software ImageJ is one of the tools that can be used for this type of analysis, standing out for being open access and simple to use. However, there is a lack of studies that apply these techniques to assess the quality of $S$. siamea seeds due to the great diversity and characteristics of forest species. In this sense, the validation of methodologies using $\mathrm{X}$-ray analysis and images of seedlings can have great benefits to the forestry sector.

Therefore, this study aimed to assess the feasibility of using the analysis of radiographic images of seeds and the digital processing of seedling images in the assessment of the physical and physiological quality of S. siamea seeds.

\section{MATERIAL AND METHODS}

\section{Site and plant material}

Five lots of S. siamea seeds obtained from ripe fruits (dry pods with predominant brown color) were collected from the middle region of the canopy of mother trees located in the metropolitan region of Natal, RN, Brazil $\left(5^{\circ} 49^{\prime} 12^{\prime \prime} \mathrm{S}\right.$ and $35^{\circ} 11^{\prime} 16^{\prime \prime} \mathrm{W}$, altitude of $70 \mathrm{~m}$ ). The set of seeds obtained from each mother tree was called a lot. Sampling was carried out within each lot and 250 seeds were randomly selected for subsequent analyses.

\section{Physical analysis}

Determination of moisture content: The seeds of each lot were subjected to the determination of moisture content 
by the oven method at $105 \pm 3^{\circ} \mathrm{C}$ for 24 hours (Brasil, 2009). Two replicates with a mass of $4.5 \mathrm{~g}$ of seeds were used for each lot. The results were expressed as a percentage (wet basis).

Acquisition and processing of digital radiographs: Four replications of 50 seeds from each lot were used to obtain the radiographic images. The seeds were fixed on transparency film containing double-sided adhesive tape to enable subsequent individual identification in the subsequent analyses. Then, the seeds were subjected to X-ray radiation for five seconds under a voltage of $27 \mathrm{kV}$ and a focal length of 27.8 from the radiation source in Faxitron MX-20 equipment (Faxitron X-ray Corp. Wheeling, IL, USA) coupled to a computer. The digital radiographic images generated were saved in TIFF format (Tagged Image File Format) and then analyzed.

Visual analyses were performed on the radiographs by quantifying the percentage of well-formed and malformed seeds, as well as automated analysis using the software ImageJ. Well-formed seeds were those that presented integument, cotyledon, and embryonic axis without physical damage, deformations, and apparent filling failures, whereas malformed seeds presented one or more of these characteristics not apparent in well-formed seeds. The macro IJCropSeed (Medeiros et al., 2020), with a standardized scale of 55.55 pixels. $\mathrm{mm}^{-1}$ and a region of interest (ROI) size limited between 20 and $50 \mathrm{~mm}^{2}$, was used in the analysis with ImageJ. The variables area $\left(\mathrm{mm}^{2}\right)$, perimeter $(\mathrm{mm})$, circularity, aspect ratio, relative density (gray.pixel ${ }^{-1}$ ), integrated density (gray. $\mathrm{mm}^{2}$ pixel $^{-1}$ ), and median gray (gray.pixel ${ }^{-1}$ ) were analyzed (Medeiros et al., 2020). In addition, three-dimensional projections were applied to some radiographic images of the seeds using false color and application of highlight texture for visual presentation.

\section{Physiological analyses}

Germination test: After performing the X-ray test, the seeds were manually scarified by sanding the opposite end to the micropyle, enough to allow water to enter and without causing damage to its internal structure (Dutra et al., 2007). Subsequently, the seeds were submitted to the germination test, maintaining the arrangement and positioning of seeds originally used in the X-ray test. The germination test was conducted on paper rolls moistened with an amount of water equivalent to 2.5 times the mass of the dry paper and maintained in a germinator with a constant temperature of $25^{\circ} \mathrm{C}$ and continuous light (Dutra et al., 2007). The final germination count was performed on the tenth day after sowing, defined based on a previous test for germination stabilization. The results were expressed as a percentage of normal seedlings. Daily counts of the number of normal seedlings were also performed to determine the germination speed index (GSI).

Digital analysis of seedling images: Dead seeds and seedlings obtained in the germination test were placed on a blue background next to a ruler graduated in centimeters and were scanned (HP, Scanjet 200) with a 300-dpi resolution and saved in JPG format. The images were transferred to a computer and processed using the software ImageJ. A manual adjustment of the seedling silhouettes was performed in the software, which allowed obtaining the seedling length. Uniformity and vigor indices were also calculated (Sako et al., 2001) from seedling length data, obtained through the package SeedCalc (Silva et al., 2019). The length results were expressed in millimeters per seedling and the indices in dimensionless values ranging from 1 to 1000 .

Seedling dry matter mass: The seedlings were packed in a paper bag and placed to dry in an air circulation oven at $65^{\circ} \mathrm{C}$ for 48 hours to determine the dry matter mass. Subsequently, the samples were removed from the oven, placed in a desiccator, and weighed to determine the mean dry matter mass per seedling, expressed in mg.seedling ${ }^{-1}$.

\section{Experimental design and statistical analysis}

The experiment was conducted in a completely randomized design. The data were submitted to analysis of variance (ANOVA). The means were compared using the Tukey test $(p \leq 0.05)$ after confirming the normal distribution of errors by the Shapiro-Wilk test and homogeneity of variances by the Bartlett test. Subsequently, multivariate principal component analysis (PCA) was performed. The software used in all statistical analyses was R (R Core Team, 2019). 


\section{RESULTS AND DISCUSSION}

The degree of seed moisture ranged from 11.5 to $12.9 \%$ between the analyzed lots. The low water content may have favored a better visualization of the internal morphology of seeds since this factor influences the optical density of X-ray images, as observed by Simak (1991). The radiographic images allowed the visualization of details of the internal morphology of seeds (Figure 1). This technique allowed differentiating the tissues of the embryonic axis, cotyledons, and integument (Figure 1a), as well as identifying well-formed seeds, seeds with physical damage caused by insects (rounded damage in the embryo and presence of holes in the seed integument), and seeds with malformed embryos (characterized by rugosity and atrophy of the embryo and integument) (Figure 1b).

The occurrence of damage caused by insects and embryonic malformation may significantly compromise the quality of the forest seed lot. However, identifying these characteristics is not an easy task. The use of the X-ray technique was satisfactory to identify these characteristics in a non-destructive, precise, and fast way. Other works have also successfully used the technique for analyzing seeds of forest species such as Tabebuia heptaphylla (Amaral et al., 2011), Acca sellowiana (Silva et al., 2013), Terminalia argentea (Gomes et al., 2014), Platypodium elegans (Gomes et al., 2016), Senna multijuga (Marchi and Gomes-Junior, 2017), Moringa oleifera (Noronha et al., 2018), Leucaena leucocephala (Medeiros et al., 2018), Lecythis pisonis (Rosa et al., 2020), Arctostaphylos pungens, Juniperus deppeana (Rubalcava-Castillo et al., 2020), and Pinus sibirica (Arkhipov et al., 2020).

No significant differences were observed between lots for the morphometric variables (area, perimeter, circularity, and aspect ratio) analyzed in the radiographic images, which indicates a homogeneous pattern of size and shape between seeds of the five lots (Figure 2). However, the tissue integrity analysis, from the variables relative density, integrated density, median gray, and percentage of well-formed and malformed seeds, allowed identifying significant differences between lots. Overall, lot 4 had the lowest tissue integrity, with significantly lower values of relative density, integrated density, and median gray, as well as higher values of malformed seeds. The other lots had a behavior that varied according to the analysis. The variables obtained with automatic analysis (relative density, integrated density,
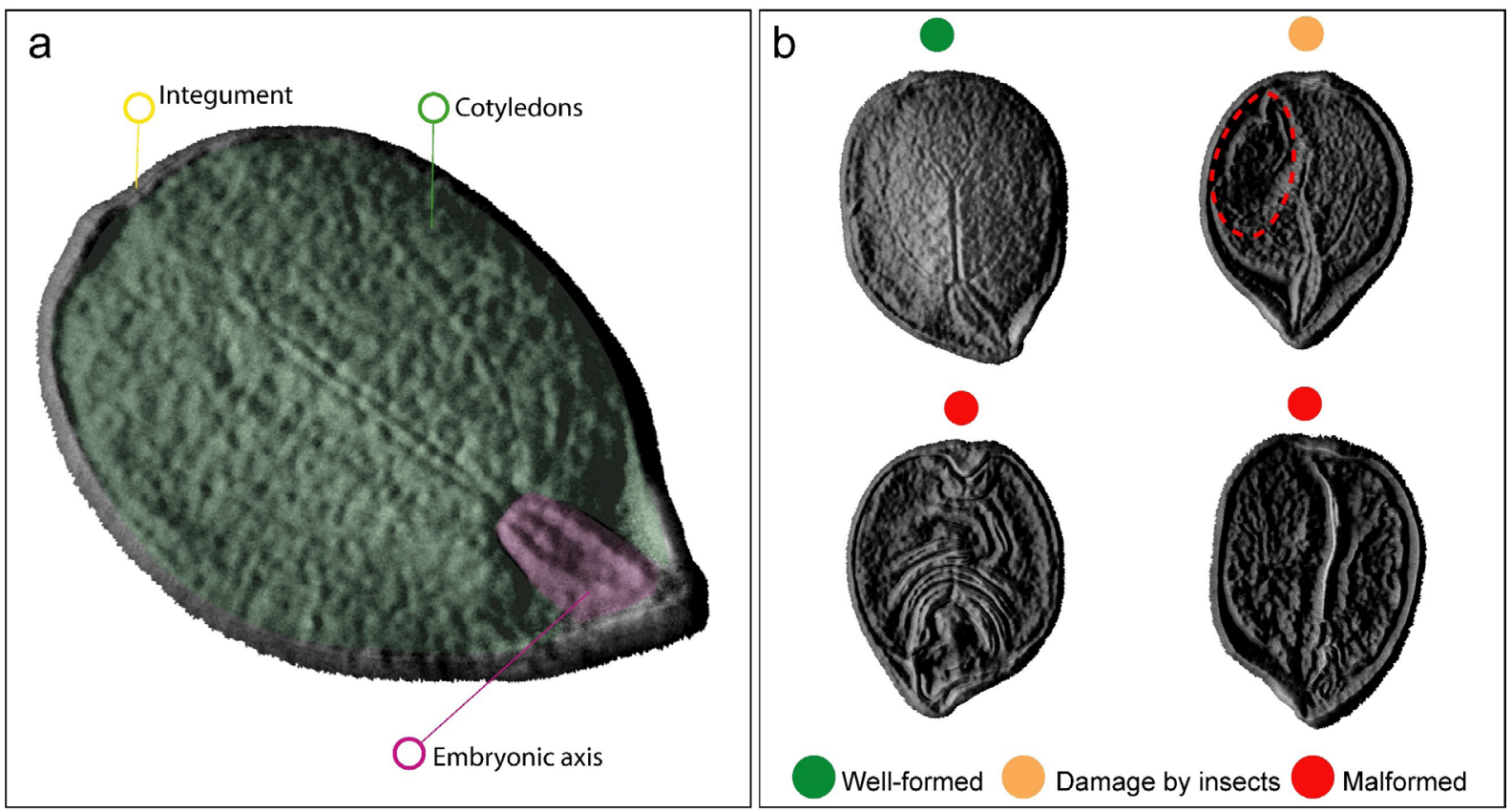

Well-formed seed showing its main parts (a) and seeds showing different characteristics, such as damage by predation and embryonic malformation (b).

Figure 1. Three-dimensional projections of radiographs of Senna siamea seeds using false color and applications of texture enhancement. 
and median gray) presented no difference only between lots 3 and 4 . Lots 1 and 2 did not differ from lot 4 in the visual analyses of well-formed and malformed seeds.

The morphometric variables showed no difference between lots although they have been constantly associated with the germinative performance of forest seeds. Marchi and Gomes-Junior (2017) observed a relationship between the area of seeds of Senna multijuga and its physiological potential. However, the authors emphasize that several aspects must be considered, such as the internal cavity occupied by the embryo and endosperm, the presence of mechanical damage, and spots indicating tissue deterioration or seed malformations, which can influence germination. This behavior has also been observed in agricultural crops, such as Brassica oleracea, in which the area of seeds showed a strong correlation with the length of its seedlings, in which larger areas coincided with higher amounts of available reserves for germinating well-formed seeds when the ripening process was completed (Abud et al., 2018).

Variables based on pixel intensity, such as relative density, integrated density, and median gray, have been used to classify seeds within physical quality levels (Abud et al., 2018; Arkhipov et al., 2020; Medeiros et al., 2018). These variables are calculated using the gray values of each pixel in the image and have a direct relationship to the resistance that the internal tissues of the seed present to the X-ray passage (Kotwaliwale et al., 2014). Thus, higher intensities of gray indicate denser tissues, i.e., there is a higher impediment to the X-ray passage, which confer a higher level of radiopacity in the seed radiography. In this study, lot 4 had the lowest levels of radiopacity, indicating less dense tissues compared to lots 1,2 , and 5 .
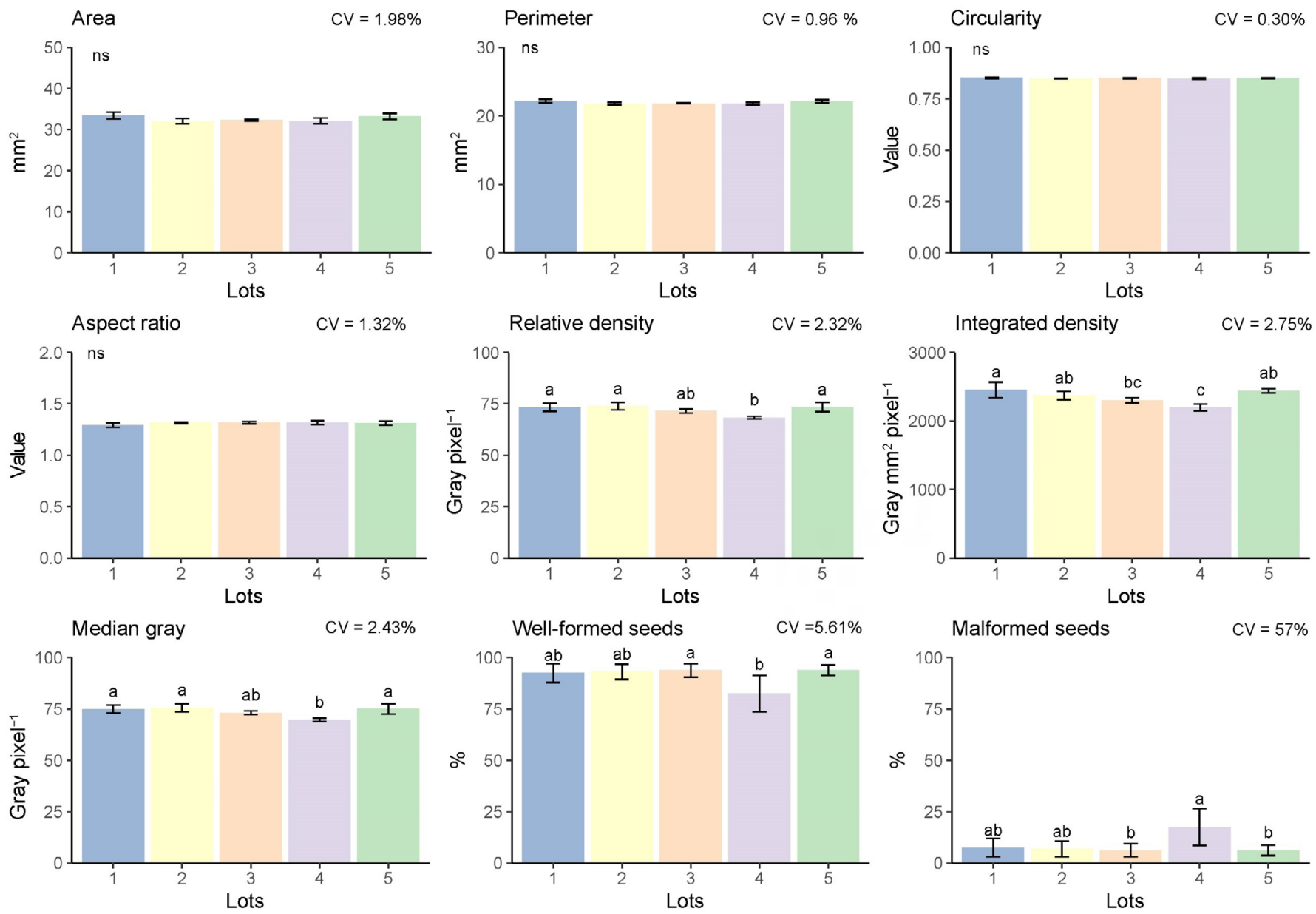

ns: non-significant difference at 5\% probability; CV: coefficient of variation. Bars represent the standard deviation.

Figure 2. Variables obtained from the radiographic analysis of five lots of Senna siamea seeds. Lowercase letter means comparison between lots for each evaluation using the Tukey test $(p<0.05)$. 
The level of X-ray absorption by seeds is mainly determined by the factors composition, thickness, and density of seed tissues and the wavelength of ionizing radiation (Kotwaliwale et al., 2014). Some studies have mentioned that the contrast used by the equipment in the image calibration must be standardized for a precise comparison between variables related to pixel intensity (Medeiros et al., 2020). In addition, other factors related to the standardization of the degree of moisture of lots and the overlap of seeds must be considered.

The variables related to the physiological potential (Figure 3) showed a significant difference between the means of lots for all the analyzed variables. Germination between lots varied from 78 to $94 \%$, and differences were observed only between lots 4 and 2 . The germination speed index differentiated lots 1, 2, and 3 from lot 4, while the dry matter differed only lot 5 from lot 4 . Digital analyses with seedling length and their uniformity and vigor indices maintained a similar behavior, in which lot 1 and 2 differed from lot 4 . In general, lot 4 showed lower performance for most of the analyzed variables.

The variables of physiological potential, mainly those of vigor related to seedling performance and germination speed, are important to attest to the physiological potential of seed lots, allowing an estimate of seed performance under real field conditions (Finch-Savage and Bassel, 2016). According to Marcos-Filho (2015), the first characteristics affected after the beginning of the seed deterioration process are the germination speed and seedling growth, with the loss of the ability to germinate being a secondary event. In this sense, the evaluation of seedling length through the digital image analysis enables achieving more accurate results of seed quality.
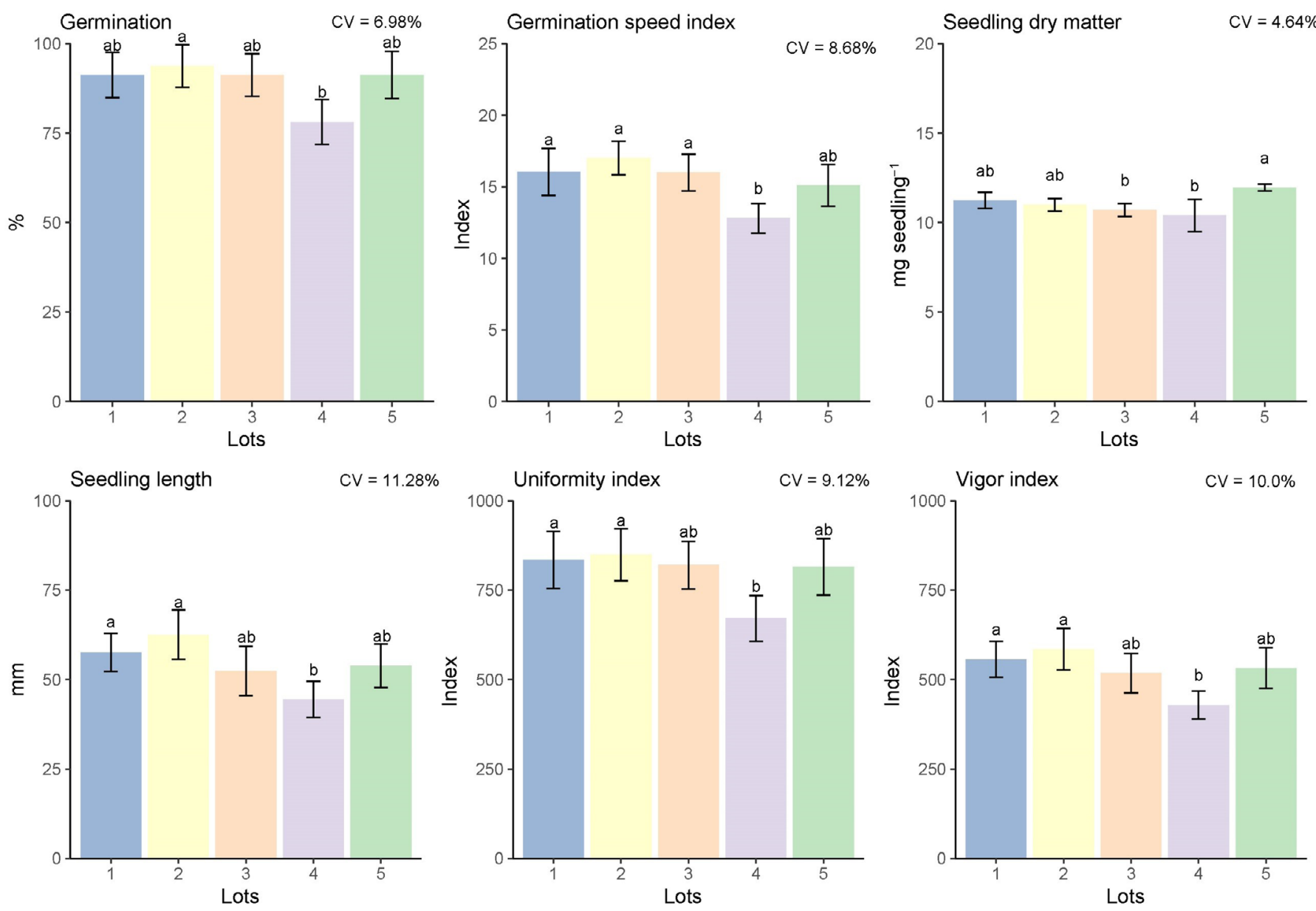

ns: non-significant difference at 5\% probability; CV: coefficient of variation. Bars represent the standard deviation.

Figure 3. Physiological analyses of five lots of Senna siamea seeds. Lowercase letter means comparison between lots for each evaluation using the Tukey test $(p<0.05)$. 
The software ImageJ allowed the measurement of seedling length. This approach has the following main advantages: the possibility of constructing a digital image base; allow subsequent analysis of seedlings; precisely adjust the measurement to the silhouettes of the seedling structures; the simplicity of analysis; allow the use of any image acquisition device; and allow the use of images with different resolutions. However, the main disadvantage of this method is the process of manual marking of seedlings, which is too time-consuming although it increases the sensitivity. Few free access software is available for automatic analysis of seedlings of forest species, standing out SAPL (Sistema de Análise de Plântulas) (Pereira et al., 2020). However, SAPL does not currently support to S. siamea. Other systems, such as SVIS (Sako et al., 2001) and Groundeye (https://www.tbit.com.br/), have also been used for automatic seedling analysis, but they are systems with a commercial license. A recent study demonstrated the application of Groundeye for the analysis of Bowdichia virgilioides Kunth seedlings, allowing the automatic measurement of cotyledon leaves, hypocotyls, and primary roots through the training of artificial intelligence models in the software (Lima et al., 2018).

The data of the five lots and fifteen characteristics were used in the multivariate principal component analysis (Figure 4). Two components (PC1 and PC2) were obtained after processing the data, representing $88.4 \%$ of the total data variability. Thus, PCA allowed reducing the dimensionality of the data, which showed a clear distinction between lots and the relationship between the studied variables.

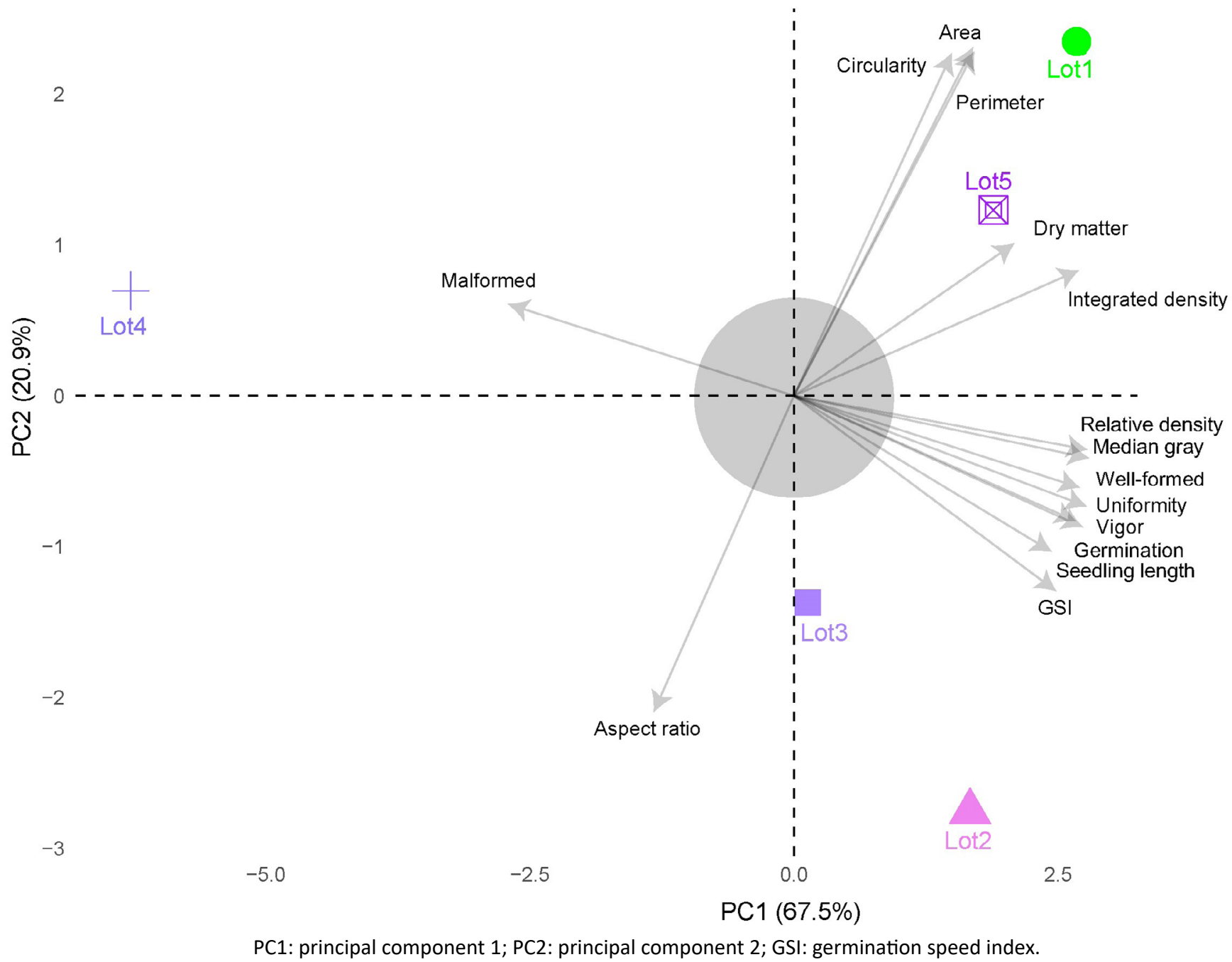

Figure 4. Biplot graph of the principal component analysis obtained from variables related to the physical and physiological characteristics of Senna siamea seeds. 
In general, the closer the vector (variable) is to the individual (lot), the higher the performance of that lot for the corresponding variable. Thus, lot 4 was located in the opposite quadrant (negative scores of PC1) to the variables of tissue integrity and physiological quality, reinforcing the results shown in Figures 2 and 3, which evidenced a lower performance of this lot for these variables. In addition, the vectors that comprise the variables obtained from radiographs were close to the vectors of physiological quality, which suggests a correlation for these characteristics.

The high correlation between easily measurable X-ray image descriptors and complex attributes of physiological quality are important findings that validate the method for evaluating the quality of $S$. siamea seeds. The variables relative density and median gray, obtained with the automatic analysis of X-ray images, showed a high correlation $(r>0.86)$ and were located in the same quadrant as the variables related to the physiological quality of seeds (vigor, uniformity, germination, seedling length, and GSI), as evidenced by the PCA analysis (Figure 3). Thus, the automatic analysis of X-ray images was effective to obtain parameters related to the physiological potential of seeds. Moreover, the vectors of the variables obtained by the analysis of seedling images were in the positive scores of PC1 and close to the vectors corresponding to GSI and germination. Thus, the seedling image analysis is efficient and sensitive to characterize the physiological quality of seeds at vigor levels (Figures 3 and 4).

Recently, researchers used information from radiographic images to develop machine learning models and achieved high accuracy in the estimation of the physiological potential of Jatropha curcas seeds, highlighting the potential of the X-ray technique for this analysis (Medeiros et al., 2020). Thus, the present study can serve as a support for future studies using artificial intelligence techniques employing radiographic images to classify $S$. siamea seeds.

\section{CONCLUSIONS}

The evaluation of Senna siamea Lam. seeds using the X-ray technique demonstrated the viability of this procedure for physical quality. The analysis of digital images of seedlings allowed to differentiate the seed lots, to characterize the physiological quality, and to associate the results of this analysis with those obtained in the physiological characterization and the X-ray analysis, showing that the technique is also efficient.

\section{ACKNOWLEDGMENTS}

This research was supported by the Consel ho Nacional de Desenvolvimento Cientifico e Tecnológico (CNPq, 141342/20200) and the Coordenação de Aperfeiçoamento de Pessoal de Nível Superior - Brazil (CAPES) - Financing Code 001.

\section{REFERENCES}

ABUD, H.F.; CICERO, S.M.; GOMES-JUNIOR, F.G. Radiographic images and relationship of the internal morphology and physiological potential of broccoli seeds. Acta Scientiarum: Agronomy, v.40, n.1, p.1-9, 2018. https://doi.org/10.4025/actasciagron.v40i1.34950

AMARAL, J.B.; MARTINS, L.; FORTI, V.A.; CÍCERO, S.M.; MARCOS-FILHO, J. Teste de raios-X para avaliação do potencial fisiológico de sementes de ipê-roxo. Revista Brasileira de Sementes, v.33, n.4, p.601-607, 2011. https://doi.org/10.1590/S010131222011000400001

ARKHIPOV, M.V.; PRIYATKIN, N.S.; GUSAKOVA, L.P.; KARAMYSHEVA, A.V.; TROFIMUK, L.P.; POTRAKHOV, N.N.; BESSONOV, V.B.; SHCHUKINA, P.A. Microfocus $x$-ray method for detecting hidden defects in seeds of woody forest species and other types of vascular plants. Technical Physics, v.65, n.2, p.324-332, 2020. https://doi.org/10.1134/S1063784220020024

BRASIL. Ministério da Agricultura, Pecuária e Abastecimento. Regras para análise de sementes. Ministério da Agricultura, Pecuária e Abastecimento. Secretaria de Defesa Agropecuária. Brasília: MAPA/ACS, 2009. 395p. https://www.gov.br/agricultura/pt-br/ assuntos/insumos-agropecuarios/arquivos-publicacoes-insumos/2946_regras_analise_sementes.pdf 
BRASIL. Ministério da Agricultura, Pecuária e Abastecimento. Instruções para análise de sementes de espécies florestais. Ministério da Agricultura, Pecuária e Abastecimento. Secretaria de Defesa Agropecuária. Brasília: MAPA/ACS, 2013. 98p. https://www.gov. br/agricultura/pt-br/assuntos/insumos-agropecuarios/insumos-agricolas/sementes-e-mudas/publicacoes-sementes-e-mudas/ instrucoes-para-analise-de-sementes-de-especies-florestais/view

CASTAN, D.O.C.; GOMES-JUNIOR, F.G.; MARCOS-FILHO, J. Vigor-S, a new system for evaluating the physiological potential of maize seeds. Scientia Agricola, v.75, n.2, p.167-172, 2018. https://doi.org/10.1590/1678-992x-2016-0401

DUTRA, A.S.; MEDEIROS-FILHO, S.; TEÓFILO, E.M.; DINIZ, F.O. Germinação de sementes de Senna siamea (Lam.) H.S. Irwin e Barneby: Caesalpinoideae. Revista Brasileira de Sementes, v.29, n.1, p.160-164, 2007. https://doi.org/10.1590/S0101-31222007000100022

ELMASRY, G.; ELGAMAL, R.; MANDOUR, N.; GOU, P.; AL-REJAIE, S.; BELIN, E.; ROUSSEAU, D. Emerging thermal imaging techniques for seed quality evaluation: Principles and applications. Food Research International, v.131, p.109025, 2020. https://doi.org/10.1016/j. foodres.2020.109025

FINCH-SAVAGE, W.E.E.; BASSEL, G.W.W. Seed vigour and crop establishment: extending performance beyond adaptation. Journal of Experimental Botany, v.67, n.3, p.567-591, 2016. https://doi.org/10.1093/jxb/erv490

GOMES-JUNIOR, F.G.; CICERO, S.M. X-Ray analysis to assess mechanical damage in sweet corn seeds. Revista Brasileira de Sementes, v.34, n.1, p.78-85, 2012. https://doi.org/10.1590/S0101-31222012000100010

GOMES, K.B.P.; CRISTO, R.C.; MARTINS, I.S.; GOMES-JUNIOR, F.G. Avaliação da morfologia interna de sementes de Terminalia argentea (Combretaceae) pelo teste de raios-X. Revista Ciência Agronômica, v.45, n.4, p.752-759, 2014. https://doi.org/10.1590/ S1806-66902014000400013

GOMES, K.B.P.; MATOS, J.M.M.; MARTINS, I.S.; CRISTO, R.C. X-ray test to evaluate the physiological potential of Platypodium elegans seeds. Research Journal of Seed Science, v.9, n.2, p.29-35, 2016. https://doi.org/10.3923/rjss.2016.29.35

HASSAN, I.A.; NASIRU, I.A.; MALUT, A.M.; ABDULKADIR, I.S.; ALI, A.S. Phytochemical studies and thin layer chromatography of leaves and flower extracts of Senna siamea lam for possible biomedical applications. Journal of Pharmacognosy and Phytotherapy, v.7, n.3, p.18-26, 2015. https://doi.org/10.5897/JPP2014.0337

KOTWALIWALE, N.; SINGH, K.; KALNE, A.; JHA, S.N.; SETH, N.; KAR, A. X-ray imaging methods for internal quality evaluation of agricultural produce. Journal of Food Science and Technology, v.51, n.1, p.1-15, 2014. https://doi.org/10.1007/s13197-011-0485-y

LIMA, J.M.E.; SMIDERLE, O.J.; OLIVEIRA, J.A.; CARVALHO, M.L.M. Técnicas de análise de imagem para caracterização da qualidade de sementes de paricarana (Bowdichia virgilioides Kunth). Ciência Florestal, v.28, n.3, p.1202, 2018. https://doi. org/10.5902/1980509833367

MARCHI, J.L.; GOMES-JUNIOR, F.G. Use of image analysis techniques to determine the embryo size of Senna multijuga (Rich.) seeds and its relation to germination and vigor. Journal of Seed Science, v.39, n.1, p.13-19, 2017. https://doi.org/10.1590/2317$1545 v 39 n 1165423$

MARCOS-FILHO, J. Seed vigor testing: an overview of the past, present and future perspective. Scientia Agricola, v.72, n.4, p.363374, 2015. https://doi.org/10.1590/0103-9016-2015-0007

MEDEIROS, A.D.; ARAÚJO, J.O.; LEÓN, M.J.Z.; SILVA, L.J.; DIAS, D.C.F.S. Parameters based on X-ray images to assess the physical and physiological quality of Leucaena leucocephala seeds. Ciência e Agrotecnologia, v.42, n.6, p.643-652, 2018. https://doi. org/10.1590/1413-70542018426023318

MEDEIROS, A.D. ; MARTINS, M.S.; SILVA, L.J.; PEREIRA, M.D.; LEÓN, M.J.Z.; DIAS, D.C.F.S. X-ray imaging and digital processing application in non-destructive assessing of melon seed quality. Journal of Seed Science, v.42, 2020. https://doi.org/10.1590/2317$1545 v 42229761$

MEDEIROS, A.D.; PINHEIRO, D.T.; XAVIER, W.A.; SILVA, L.J.; DIAS, D.C.F.S. Quality classification of Jatropha curcas seeds using radiographic images and machine learning. Industrial Crops and Products, v.146, p.112162, 2020. https://doi.org/10.1016/j. indcrop.2020.112162

MEDEIROS, A.D.; SILVA, L.J.; SILVA, J.M.; DIAS, D.C.F.S.; PEREIRA, M.D. IJCropSeed: an open-access tool for high-throughput analysis of crop seed radiographs. Computers and Electronics in Agriculture, v.175, p.105555, 2020. https://doi.org/10.1016/j. compag.2020.105555 
MUND, N.K.; DASH, D.; BARIK, C.R.; GOUD, V.V.; SAHOO, L.; MISHRA, P.; NAYAK, N.R. Chemical composition, pretreatments and saccharification of Senna siamea (Lam.) H.S. Irwin and Barneby: an efficient biomass producing tree legume. Bioresource Technology, v.207, p.205-212, 2016. https://doi.org/10.1016/j.biortech.2016.01.118

NORONHA, B.G.; MEDEIROS, A.D.; PEREIRA, M.D. Avaliação da qualidade fisiológica de sementes de Moringa oleifera Lam. Ciência Florestal, v.28, n.1, p.393-402, 2018. https://doi.org/10.5902/1980509831615

PARVEEN, S.; SHAHZAD, A.; SAEMA, S. In vitro plant regeneration system for Cassia siamea Lam., a leguminous tree of economic importance. Agroforestry Systems, v.80, n.1, p.109-116, 2010. https://doi.org/10.1007/s10457-010-9301-3

PEREIRA, M.D.; REIS, J.A.; FERRARI, C.D.S.; VALE, A.M.P.G. Processamento digital de imagens de plântulas na avaliação do vigor de sementes de Moringa oleifera Lam. Ciência Florestal, v.30, n.2, p.291-306, 2020. https://doi.org/10.5902/1980509825750

PINHEIRO, D.T.; CAPOBIANGO, N.P.; MEDEIROS, A.D.; CAIAFA, K.F.; DIAS, D.C.F.S.; PINHEIRO, A.L. Assessment of the physical and physiological quality of Piptadenia gonoacantha (Mart.) J. F. Macbr seeds using image analysis. Revista Árvore, v.44, p.4426, 2020. http://dx.doi.org/10.1590/1806-908820200000026

R CORE TEAM. R Development Core Team. In R: A Language and Environment for Statistical Computing, v.55, p.275-286, 2019. https://doi.org/http://www.R-project.org

ROSA, T.L.M.; ARAUJO, C.P.; KAMKE, C.; FERREIRA, A.; FERREIRA, M.F.S.; OLIVEIRA, J.P.B.; SCHMILDT, E.R.; LOPES, J.C.; MENGARDA, L.H.G.; OTONI, W.C.; SANTOS, A.R.; ALEXANDRE, R.S. Sapucaia nut: morphophysiology, minerals content, methodological validation in image analysis, phenotypic and molecular diversity in Lecythis pisonis Cambess. Food Research International, v.137, p.109383, 2020. https://doi.org/10.1016/j.foodres.2020.109383

RUBALCAVA-CASTILLO, F.A.; SOSA-RAMÍREZ, J.; LUNA-RUÍZ, J.J.; VALDIVIA-FLORES, A.G.; DÍAZ-NÚÑEZ, V.; ÎÑIGUEZ-DÁVALOS, L.I. Endozoochorous dispersal of forest seeds by carnivorous mammals in Sierra Fría, Aguascalientes, Mexico. Ecology and Evolution, v.10, n.6, p.2991-3003, 2020. https://doi.org/10.1002/ece3.6113

SAKO, Y.; MCDONALD, M.B.; FUJIMURA, K.; EVANS, A.F.; BENNETT, M.A. A system for automated seed vigour assessment. Seed Science and Technology, v.29, n.3, p.625-636, 2001. https://www.eurofinsus.com/media/162083/seed-vigor-imaging-system

SILVA, L.J.; DIAS, D.C.F.S.; SEKITA, M.C.; FINGER, F.L. Lipid peroxidation and antioxidant enzymes of Jatropha curcas L. seeds stored at different maturity stages. Acta Scientiarum. Agronomy, v.40, n.1, p.34978, 2018. https://doi.org/10.4025/actasciagron.v40i1.34978

SILVA, L.J.; MEDEIROS, A.D.; OLIVEIRA, A.M.S. SeedCalc, a new automated R software tool for germination and seedling length data processing. Journal of Seed Science, v.41, n.2, p.250-257, 2019. https://doi.org/10.1590/2317-1545v42n2217267

SILVA, V.N.; SARMENTO, M.B.; SILVEIRA, A.C.; SILVA, C.S.; CICERO, S.M. Avaliação da morfologia interna de sementes de Acca sellowiana O. Berg por meio de análise de imagens. Revista Brasileira de Fruticultura, v.35, n.4, p.1158-1169, 2013. https://doi. org/10.1590/S0100-29452013000400027

SIMAK, M. Testing of forest tree and shrub seeds by X-radiography. In: Tree and shrub seed handbook. Zurich: ISTA, 1991. p.1-28.

TODA, Y.; OKURA, F.; ITO, J.; OKADA, S.; KINOSHITA, T.; TSUJI, H.; SAISHO, D. Training instance segmentation neural network with synthetic datasets for crop seed phenotyping. Communications Biology, v.3, n.1, p.1-12, 2020. https://doi.org/10.1038/s42003020-0905-5

TRUJILLO, H.A.; GOMES-JUNIOR, F.G.; LARA, I.A.R.; CICERO, S.M. Radiographic analysis and performance of coffee seeds. Journal of Seed Science, v.41, n.4, p.431-440, 2019. https://doi.org/10.1590/2317-1545v41n4221804

XIA, Y.; XU, Y.; LI, J.; ZHANG, C.; FAN, S. Recent advances in emerging techniques for non-destructive detection of seed viability: A review. Artificial Intelligence in Agriculture, v.1, p.35-47, 2019. https://doi.org/10.1016/j.aiia.2019.05.001 